\title{
RE-CODING ETHICS OF URBANISM FROM THE PERSPECTIVE OF THE QURAN
}

Received July $27^{\text {th }}, 2020$ | Accepted September 15 $5^{\text {th }}, 2020 \mid$ Available online June $15^{\text {th }}, 2021 \mid$

DOI http://dx. doi. org/10.18860/jia.v6i3. 10032

Alaa Abdelhamid Elmanzlawi

Architecture Department

Faculty of Fine Arts

Mansoura University

Mansoura, Egypt

alaa.elmanzlawi@mans.edu.eg

\begin{abstract}
This paper aims to identify and discuss core concepts of importance to the ethics of urbanism by undertaking a detailed study of urban issues in the light of the Holy Quran based on their associated ethical dimensions and the nature of the urban structure. This study attempts to analyze the concepts of ethical urbanism by conducting a thorough content analysis of urbanism themes within the divine message of Muslims (the Quran) and related prior literature focusing on their related ethical aspects. The Islamic view of ethical urbanism is systematic and unambiguous. The analyzes identified 1819 verses in all 30 sections of the Quran, including five themes linked to urban Structure Quality and Ethical Responsibility. Particularly environmental, physical, social, economic, and political responsibility. This urban content and the associated principles are embedded in the idea that men are God's rulers on earth and their deeds have earthly and celestial benefits. This paper leads to the intellectual growth of Islam through promoting involvement in litihad. Therefore, this is the interest of urban scholars and responsibility to properly urban practices and religious traditions.
\end{abstract}

KEYWORDS:

Sustainability; Urban Ethics; Islamic Ethics; Sacred Texts; Shari'ah.

\section{INTRODUCTION}

Urbanism is a name for building and its converse, devastation. It is also called material development and cultural, spiritual, and value revitalization. God states: "..., and they plowed [or excavated] the earth and built it up more than they [i.e., the Makkans] have built it up..." (Ar-Room:9). Besides, it needs to conserve the basic principles of dignity and human coexistence to foster social and inter-community harmony and community affiliation. As this verse has explained, "Our Lord, I have settled some of my descendants in an uncultivated valley near Your sacred House, our Lord, that they may establish prayer. So, make hearts among the people incline toward them and provide for them from the fruits that they might be grateful." (Ibrahim:37). It means that the fundamental pillars of urbanism are: total familiarity, adequate abundance, and a contented soul. Thus, the achieving of urbanism requires both moral and material construction together. It was, therefore, the demise of the ethical condition that signaled the demise of urbanism. God says, "Have they not seen how many generations We destroyed before them which We had established upon the earth as We have not established you? And We sent [rain from] the sky upon them in showers and made rivers flow beneath them; then We destroyed them for their sins and brought forth after them a generation of others" (Al-An'aam:6). Consequently, we need ethical urbanization to achieve urbanization.

Though religion may have a significant impact on the actions of people, communities, and culture as a whole [1], particularly the three Monotheistic Religions and their effect on human attitudes and behavior of individuals/groups (Abrahamic Religions: Judaism, Christianity, and Islam). However, there remains a lack of empirical evidence: to what degree urban ethics are promoted by divine textual messages, urban styles of themes found in these sacred texts, and their influence on urban practice. In other words, there is no specific meaning of the essential expression 'ethical urbanism' as described above. This may seem that the correct concept for "ethical urbanism" should be taken from central Islamic holy scriptures, particularly the Holly Quran, by identifying its basis, its framework, its characteristics, and classifying its values.

This paper explores and identifies foundations, pillars, ideal patterns, characteristics, and principles of ethical urbanism drawn from the Holy Quran. The Holy Quran does not explicitly say specifics, but eternal ideas and concepts are suggested to develop an adequate built environment for ethical existence. The current paper, therefore, aims to fill this noticeable gap in urban ethics. In other terms, the paper's fundamental hypothesis is that the characteristics and meaning of ethical urbanism may be taken from the Holy Quran through research question: What are the key ideas and concepts of ethical urbanism aspects to consider? 


\section{BACKGROUND AND DEVELOPMENT OF RESEARCH QUESTIONS}

\section{Islam: An Overview}

As Muslims believe, Islam is the end of monotheistic religions, and the Quran is the human being's last revelation. The Qur'an was sent to all humanity as a Constitution, organizing and regulating life, labor, and ties, according to Islamic teachings. Accordingly, both the Qur'an (the word of God) and the Sunnah (the words and actions of the Prophet Mohammed) are the two primary sources of the Islamic law-Sharia as the Prophet Mohammed said, "I have left with you two things which, if you follow them, you will never go astray: The book of God (in which there is right guidance and light) and the sunnah of His Prophet." Sharia has two significant elements: worship (ibadah) and transaction (muamalah). The first is the relationship of worship between humans and God. The latter refers to the relation between individuals in everyday life. Both elements work together to advance the welfare of all people. Sharia lays out four values guiding socioeconomic life: unity (tawhid) in which individual acts are expected to adhere to an interconnected whole; equilibrium (al'adl wal ihsan), in which persons have the right to behave without harm to others; freewill (ikhtiyar), in which a broader societal framework governs the protection of the person's rights; and responsibility (fardh), in which individuals and the society have accountability [2][3][4][5]. Therefore, the human must discharge his ethical duty towards society, especially the urban world, as a central part of his religion.

\section{First: The Essentiality of Religious in Human Life:}

If religion, in general, is an argumentative term that means faith, and it is usually defined as a belief Associated with supernatural Holy and divine. While the philosophical lexicon provides a definition of religion that expresses the relationship between the absolute and the limited, any religion is characterized by the following [6]: (Absolute Belief - Determine the Relationship of The Individual to This Absolute - Practicing Certain Rites). Religion is an integral part of human instinct and a fundamental human need that is not indispensable. Thus, religion is essential for societies and the members of these societies. As well as the human being's need for religion is not secondary or marginal. It is a crucial need related to the essence of life and the mystery of existence.

\section{Second: The Compatibility between Religion and Hu- man Values.}

In the Islamic religion, the first Hijri century teachings on morality and moral conduct for Muslims to adopt a morally upright character. Showing kindness to people and charity to the poor and the helpless [7]. The Quran and the Hadith - the central religious texts of Islam serve as the primary source for these teachings. This is how religion worked to respect human values, cared about them, and drew upon them after the world wars overwhelmed human values, and almost modernism almost dominated them [8].

Third: The Compatibility between Religion and Ethical Values

Ethics until recently has been a brainchild of religion and thus an essential part of religion from which it is inseparable. This assumption has led some scholars to hold that there can be no ethics without religion since ethics is intrinsically a part of religion. Hence, this compatibility between religious and ethical values plays an active role in communities' lives, especially when those who believe in them convert to behavior in their practical life [9][10].

\section{METHODS}

\section{RESEARCH DESIGN}

In Islam, the Quran is not only the principal pillar of Muslim religion and religious activity but also a whole divine instruction in all human issues of life: "... And We have sent down to you the Book as clarification for all things and as guidance and mercy and good tidings for the Muslims" (An-Nahl:89). To human beings, as essential guidance, the Qur'an states: "Indeed, Allah orders justice and kindness and giving to relatives and forbids shameful acts and evil deeds and transgression. He admonishes you that perhaps you will be reminded" (An-Nahl:90). Throughout this respect, the Quran has been deemed a valuable and rich source of textual content to be studied in order to figure out whether and to what degree the idea of urban responsibility was expressed and conveyed to all human beings. In view of the research questions of this study, an approach was applied to both the quantitative and qualitative content analyzes of the Quranic text, aiming to analyze and understand the volume and significance of verses within the context of Quranic ethics for urban responsibility. Any non-Arabic Quranic text is not a Quranic translation based on the context in which it was revealed the meaning of verses in Quran: "Indeed, it is We who sent down the message [i.e., the Qur'ān], and indeed, We will be its guardian" (AlHijr:9). An Arabically authenticated Quran interpretation was originally chosen to address this matter [11] [12][13]. At the side of the Quranic text, this interpretation was read carefully in its entirety, using the researcher (Muslim and Arabic local speaker), who used all the Quranic verses which contained references to the interplay between the human being and urbanism [14]. This method did not only seek to count verses comprising such terms (connected with urbanism). Every verse was interpreted closely in terms of its meaning and motives for revelation, and many verses were overlooked. Therefore, 754 verses with environmental content were found; 319 verses have been identified as verses with physical content, 288 verses with social content were listed, 243 verses have been classified as economic content verses, and 215 verses have been described as political verses. An analysis of urban structure research showed that the urban content is generally categorized into five major themes: environ- 
mental, physical, social, economic, and political. However, such research concentrated more on the impacts on urban activity than on the categories/themes in Ethical urbanism fields. While the Qur'an is the creator's word to human beings in Islam, Qur'anic verses of urban substance have been found to encourage a rational engagement of urban development in an ethical manner involving a high degree of respect towards granted city context. For example, environmental verses were described as promoting environmentally friendly usage, which needs a high degree of respect for the environment.

According to the analysis of contemporary urban planning approaches theories, a checklist of urban themes was developed and then piloted/tested by the author (Muslim, native Arabic speaker), with an established record of high-quality publications on this subject. After reviewing the different assessment tools for ethical urbanism evaluation, the final checklist was refined through all identified verses. It covered five main themes: refer to various aspects of Quranic responsibility about recoding the ethics of urbanism. It was divided into 15 Urban Structure Quality (USQ) (See Tables 2,3,4,5 and 6).

To explore Basic Needs (BN), Ethical Aspects (EA), and design guidelines in urban design practices, which are based on the various religious and ethical values of urbanism in Egyptian cities, urban designers consider the relationships between 33 Urban Structure Indicator (USI). These Ethical Needs Situations range from the physical to the nonphysical aspects in urban design dimensions (UDD). Since The function of urban design through the classified document relates to the relationship between man and the built environment can be represented in 7 common dimensions (UDD). The UDD contains perceptual, functional, visual, temporal, behavioral, Socio-Cultural, and environmental dimensions [15][16].

\section{EMPIRICAL RESULTS OVERALL DESCRIPTIVE}

Through the Quranic message, the five main themes refer to different aspects of the ethics of urbanism; The first theme, Quranic Environmental Responsibility, refers to the natural Ethical Needs aspects of urbanization. As Table 1 shows, 754 verses (11\%) over the whole 30 parts show evidence for Ethical Needs Indicators (HNI) towards human and natural resources. The second theme, Quranic Physical Responsibility, refers to facilities, urban fabric, land use, services and facilities, and infrastructure. It also discusses the accessibility, traffic, and transportation issues. Furthermore, it discusses the issues concerning citizens' feelings toward its community, such as the identity of the place. As seen in Table 1, there are 319 verses (5\%) for Ethical Needs Indicators (HNI) towards physical planning. The third theme, Quranic Social Responsibility, includes the Ethical Needs aspects that refer to the social dimension of urbanization and the relationship between people. The questions regarding individual choices and the participation of citizens are illustrated in table 1 that there are 288 verses (5\%) for Ethical Needs Indicators ( $\mathrm{HNI}$ ) towards communities and societies. The fourth theme, Quranic Economical Responsibility characterizes the community as a place of economic activities; it indicates in table 1, there are 243 verses (5\%) for Ethical Needs Indicators ( $\mathrm{HNI}$ ) to promote and safeguard sustainable economic development and the eradication of hunger and extreme poverty of these. The fifth theme, Quranic Political Responsibility, refers to the city policies that support urban quality of life and how these policies are implemented. In table 1, there are 215 verses (5\%) for Ethical Needs Indicators ( $\mathrm{HNI}$ ) towards Policy priorities for action on equalization of opportunities in the context of development.

\begin{tabular}{|c|c|c|c|c|c|}
\hline Themes & Items & $\begin{array}{c}\text { Chap- } \\
\text { ters (\%) }\end{array}$ & Verses & $\%$ & $\begin{array}{c}\% \text { of } \mathrm{T} \\
\text { Verses }\end{array}$ \\
\hline & $\begin{array}{l}\text { The whole } \\
\text { Qur'an }\end{array}$ & $114(100)$ & 6,236 & 100 & $\mathbf{N} / \mathbf{A}$ \\
\hline \multirow{6}{*}{$\begin{array}{l}\text { Qur'anic Envi- } \\
\text { ronmental } \\
\text { Responsibility }\end{array}$} & Air & $18(16)$ & 24 & 0.4 & 3 \\
\hline & Water & 49 (43) & 106 & 2 & 14 \\
\hline & Land & $52(46)$ & 166 & 3 & 22 \\
\hline & Energy & $67(59)$ & 248 & 4 & 33 \\
\hline & $\begin{array}{c}\text { Local Envi- } \\
\text { ronment }\end{array}$ & $84(74)$ & 210 & 4 & 28 \\
\hline & Total & - & 754 & 11 & 100 \\
\hline \multirow{5}{*}{$\begin{array}{l}\text { Qur'anic } \\
\text { Physical Re- } \\
\text { sponsibility }\end{array}$} & Land Use & $29(25)$ & 61 & 1 & 19 \\
\hline & $\begin{array}{l}\text { Housing \& } \\
\text { Buildings }\end{array}$ & $51(45)$ & 137 & 2 & 43 \\
\hline & $\begin{array}{l}\text { Community } \\
\text { Identity }\end{array}$ & $39(34)$ & 88 & 1 & 28 \\
\hline & Mobility & $27(24)$ & 33 & 1 & 10 \\
\hline & Total & - & 319 & 5 & 100 \\
\hline \multirow{3}{*}{$\begin{array}{c}\text { Qur'anic } \\
\text { Social Respon- } \\
\text { sibility } \\
\end{array}$} & Social Equity & $38(33)$ & 164 & 3 & 57 \\
\hline & $\begin{array}{c}\text { Social Inte- } \\
\text { gration }\end{array}$ & $40(35)$ & 124 & 2 & 43 \\
\hline & Total & - & 288 & 5 & 100 \\
\hline \multirow{3}{*}{$\begin{array}{l}\text { Qur'anic Eco- } \\
\text { nomical Re- } \\
\text { sponsibility }\end{array}$} & $\begin{array}{c}\text { Economic } \\
\text { Development } \\
\text { Economic }\end{array}$ & $13(11)$ & 190 & 3 & 78 \\
\hline & $\begin{array}{c}\text { Standard of } \\
\text { Living }\end{array}$ & $17(15)$ & 53 & 1 & 22 \\
\hline & Total & - & 243 & 5 & 100 \\
\hline \multirow{3}{*}{$\begin{array}{c}\text { Qur'anic } \\
\text { Political Re- } \\
\text { sponsibility }\end{array}$} & $\begin{array}{l}\text { Urban Poli- } \\
\text { cies and }\end{array}$ & $24(21)$ & 66 & 1 & 31 \\
\hline & $\begin{array}{l}\text { Civil and } \\
\text { Political }\end{array}$ & $39(34)$ & 149 & 2 & 69 \\
\hline & Total & - & 215 & 5 & 100 \\
\hline
\end{tabular}

The rest of the empirical results section outlines how the Qur'an urges human beings to care for, protect, and adequately use different Aspects. Each aspect has an Indicator to measure it across the five themes. This will be followed by situations for Ethical Needs practice in a separate section. 


\section{QURANIC ENVIRONMENTAL RESPONSIBILITY}

A healthy natural environment contributes to public health. Therefore, the environmental situations inside human settlements are a relevant subject; populace growth and financial development affect the herbal ecosystems of each land and sea. It is far argued that the cities must be part of nature, now not as something present out of its doors. Nature inside the metropolis is a long way extra than bushes and gardens, and weeds in sidewalk cracks and vacant plenty. The air we breathe, the earth we stand on, the water we drink and excrete, and the organisms with which we share our habitat [17]. The Qur'an highlights the fact that everything was created by God, who has made it subject to the human being: "He has subjected to you whatsoever is in the heavens and the earth; all is from Him. Surely, there are signs in this for people who contemplate" (Al-Jathiah:13). This displays that humans well-known the earth in trust on behalf of God and are below an obligatory responsibility to guard and preserve all herbal assets, averting exploitation, distraction, abuse, pollutants, and to shield it from turning into scarce "We offered the trust to the heavens, and the earth, and the mountains, but they refused to bear it and were afraid of it, and the human carried it. Surely, he is a harm doer, and ignorant." (Al-Ahzab:72) [18] [19]. Failing to achieve these neglects one's responsibility in retaining the balance God created, and in turn, neglects one's responsibility and duty closer to protecting other creatures. The physical aspects of the natural environment, which have a sizeable effect on existence in towns, are as follows.

\section{QURANIC PHYSICAL RESPONSIBILITY}

The physical environment is an important aspect of human life. Consequently, it was not the new thing that was first accompanied by the emergence of Islam - it is an old process of civilizations that preceded Islam- When the human being fell on earth in order to perform the required tasks more efficiently lies in the worshipping of God. His successor in the colonization of land, what is new, is how the Islamic religion's teachings are covered by the provisions that regulate the reconstruction processes and control over their balance and objectives. God states, "After them, We made you their successors in the earth so that We might see how you would do" (Yunus:14).

The physical environment is the tangible part of the reconstruction and urbanization process that concerns man's environment. It creates an environment for human activity from personal homes and buildings to neighborhoods and towns, often including their supporting infrastructure. God says, ".... It is He who made you from the earth and let you lives upon it...." (Hood:61). Many aspects of the built environment make up a city and promote good living conditions for neighborhood residents. The urban environment that has been created also helps people to feel where they live and has a strong impact on natural environment sustainability; "No sooner does he leave than he has- tens about the earth to corrupt there and destroy crops and cattle. Allah does not love corruption" (Al Baqarah:205) [18][19]. The physical aspects of the physical environment that have a major effect on community existence are as follows.

\section{QURANIC SOCIAL RESPONSIBILITY}

A significant part of the Quran was taken by human beings as an environment element, referred to in 525 verses in 75 chapters. Humans are part of the cosmos, the elements of which complement one another, but a separate component as members with intelligence and obey God's orders.

They are preferred by God, which causes all other environmental elements to honor them and serve them. In this context, God states: "We have honored the children of Adam and carried them on both land and sea. We have provided them with good things and greatly preferred them above much of Our creation." (Al-'Isra':70).

Space and society are directly connected, a 'place' without social content is not easy to conceive, and a society without a spatial dimension is equally difficult to conceive. Individuals in a community must cooperate and connect to achieve social cohesion of communities; "... The earth will be a dwelling place for you and an enjoyment for a time" (Al 'A'raf:24). Social responsibilities, regarding social conditions and social relations between groups, networks, organizations, the state, and their senses of being part of the area, in Islam should be envisaged as a concept of fairness, social cohesion, and social inclusion.

For example, God says, "Allah has promised those of you who believe and do good works that $\mathrm{He}$ will indeed make them successors in the land as $\mathrm{He}$ made those who were before them successors..." (AnNoor:55) [18][19]. Thus, it can be inferred that at the very root of the philosophy of social accountability remain three familiar concepts: Social justice and equality, social ties, and behavioral Performance.

\section{QURANIC ECONOMICAL RESPONSIBILITY}

Reflection on the verses of the Holy Qur'an and the laws of Islam reveals to us an integrated economy that solves the humanitarian, economic problem from its roots. God has commanded us to work for the production where earth refers to money and walking humans in it, expressing work. By intermingling both of these elements (money and work), different goods, services, and industries meet his various needs.

In the Quran, God states, "Thul Karnain (Two Horns( " .They said, 'Look, Gog and Magog are corrupting the earth. Build for us a barrier between them and us, and we will pay you a tribute'. He replied: 'That which my Lord has given me is better, therefore help me with all your power, and I will build a barrier between you and between them. Bring me ingots of iron'. After he had leveled between the two cliffs, he said: 'Blow.' When he made it a fire, he said: 'Bring me molten copper so that I may pour over it. After that, they could neither scale it, nor could they pierce it" (Al- 
Kahf:94-97). That is where we find that a contract was concluded between the people and Thul Karnain (Two Horns) (Build for us a barrier / pay you a tribute). The verse dealt with the theory of supply and demand, mixing production elements such as engineering, workers, tools, building materials, the importance of science in work, the importance of having money, labor, and materials for production. The Qur'an did not forget the element of ethics. He replied, "That which my Lord has given me is better..." This part of the verse shows that this Thul Karnain was not seeking to achieve profit, but his purpose was to help the people.

One of the most critical factors affecting the prosperity of urban communities is their ability to purchase goods and services, obtain adequate food and housing, and participate in the broader community. God says: "Believers, spend of the good you have earned and of that which We have brought out of the earth for you..." (Al Baqarah:267) [18][19].

\section{QURANIC POLITICAL RESPONSIBILITY}

The word (Politics) was not mentioned in the Holy Quran, nor is any term derived from it as a description or verb. Still, the Quran came with what it indicates and predicts about it, such as the word (governance), which means ruling, ordering, forbidding people, and leading them in their affairs. This was stated in the Qur'an in various forms and methods, some of which are praise, and some are infamy. The Qur'an mentioned in the excellent governance; "... We gave the family of Abraham the Book and Wisdom, and a great kingdom" (An Nisa':54). Also, God says, "Allah orders you all to hand back trusts to their owners, and when you judge between people, you judge with justice. Indeed, the best is the exhortation with which Allah exhorts you. Allah is the Hearer, the Seer" (An Nisa':58).

Furthermore, fields that the Quran fully covered appeared in legislation, controlling values, or ruling goals. Through verses revealed by a political stance (in the contemporary term) with its economic and social dimensions that clarify the link between these stances and beliefs, judgments are made. Regarding the development of urban policies, strategies, laws, legislation, and urban design codes and guidelines, national policies play a significant role. They should encourage participation in civil and political life. Among the Quranic rulings is what deals with the actions of the individual or group related to public affairs. Some verses command Muslims to consult in their general matters: "..., and their affairs are by consultation; ..." (Ash-Shurah:38) [18][19].

\section{FINDINGS}

After studying the concept of Ethical Urbanism given verses from the Qur'an, the researcher figured out that while several scholars in diverse fields such as scientific, academic, professional, and political fields talking about "Ethical Urbanism," and "Ethics concept of Urban Design" (Utopia), the concepts of "ethical urbanism" are not clear. Knowing that urbanism is one of the most significant purposes of the Quran includes goodness, justice, and probity on both the material and moral aspects of life. Obviously, in Islamic fundamental holy texts, particularly from the Holy Quran, a few basic meanings and critical attributes of "Ethical Urbanism" spread out. In other words, therefore, the correct description would come from the Holy Quran for "Ethical Urbanism." Its essential and primary qualities in the Holy Quran are no value for material urbanism if it does not go hand in hand with realizing profound spiritual and moral values based on God's commands and laws.

It became clear how the ethical teachings at the Quranic texts include many aspects of reconstruction and urbanism consistent with a comprehensive and integrated approach that considers all other factors, including all aspects of life and what a human being needs to live as an aspect of the scientific miracle in the Quran. These signs have sometimes been explained in general and sometimes in detail, in addition to identifying the essential controls for Reconstruction and Urbanism and taking advantage of this in the modern and contemporary urbanism process. Indeed, the study results have many implications not only for Muslim societies but also for other cultures. According to the Quranic ethics, which are entirely at variance from much work and practices in reality, as seen in Tables $2,3,4,5$ and 6, it presents the definitions of Urban Structure Quality (USQ) across the five themes and Urban Structure Indicator (USI), including their Ethical Aspects (EA) in usage and protection, which supported by evidence from The Qur'anic verses (QE). Furthermore, From the review above, the subjects' critical findings and issues that clarify the attributes of principles and their application can be classified to design and identify ethical urbanism based on the Holy Quran verses among the five points.

The first issue is principles and values: In this same vein, the Islamic divine book reveals several values and meanings, including veracity, faith, optimism, reformation, and so on, which should be considered in all acts. From these observations, it is apparent that the concepts of related values and principles should be varied concerning the implementation of Common Principles in Islamic architecture and urban design and introduced by indicating the reference verses of the Holy Quran so that as many citizens can grasp them as possible. The most significant Principles and Values are justice, equality, hierarchy, truth, elegance, liberty, etc. These principles, however, are defined by classifying the values and ethics of duty toward the surrounding environment as something "subjective" and "objective" jointly.

The second issue is Attributes and Acts of Allah that man is God's vicegerent on earth, according to the Holy Qur'an Therefore attributes of the deeds of Man ought to be like those of the acts of God. In this same vein, human beings who are God's vice-gerents must embody these qualities, appears to achieve the best way of the creation, maintenance of an appropriate 
environment for the life and development of the earth, and harmonize their acts and practices with the moral standards laid down by God in the surrounding context.

The third issue is the regulation of social interaction, which is often influenced by the partnership between Man and society and the characteristics that can illustrate a Muslim culture. Therefore, the urban designer should consider the message of the Holy Quran as revealed to Prophet Muhammad and as inscribed in his Sunnah to reform people's attitudes. They are as follows: Bravery, respect, experience, fairness, justice, honesty, and knowledge pursuit.

The fourth issue is Nature and Natural Elements, which is based on Man's existence and acts on earth, taking advantage of nature and natural resources. The urban designer should start by Recognition of spiritual meaning and material benefits of nature and natural elements and considered them based on human practices and interactions between man and nature.

The fifth issue is Attributes of the Built Environment obtained from verses of the Holy Quran that define the elements and qualities of the built environment and their relationships with humans. Additionally, The Holy Quran reveals. Numerous urban and architectural suitable or unsuitable features regard identifying the characteristics of ethical urbanism, aiming to achieve a prosperity of the essential universal and fun- damental concepts of Islamic and urban planning.

Furthermore, this issue operates so broad and requires understanding by artists, environmentalists, social scientists, and so on, not just architects and urban planners, by thoroughly paying attention to the scriptures of the Holy Qur'an gathered here.

\section{DISCUSSION}

Considering the value of ethical urbanism from the viewpoint of the Quran, we conclude that whathelpfuleful for current human societies and the surrounding environment is to reform by maintaining universe order through ethical principles and civilized reconstruction. As mentioned earlier, this process should be based on the methodological aspect in Qur'anic management and interpretation.

Finally, it should be kept in mind that Quran emphasizes that determining the responsibility of people must always be considered. By explaining the connection between the term (corruption) and the word (earth) is an indication that the phenomenon of corruption that the Qur'an refers to is not an individual phenomenon or limited; it is a widespread phenomenon in the human community that must be addressed and resolved. And the term (corruption) is matched in the Holy Qur'an with the term (reform), which may interpret it as there are always processes and attempts to ruin life and corrupt its system. 
Table 2 Qur'anic Environmental Responsibility: ENS, EA, and GG, based on the 5 HNA, 11 HNI, and 3 UDD, source: (author)

Table 2 Qur'anic Environmental
Themes $\quad$ Qur'anic Environmental Responsibility

Urban Struc-
ture Indicator

(USI)

Qur'anic Evidence (QE)

It was not in play that We created the heavens

and the earth and all that is between them. (AdDukhan, 38).

Atmospheric And We send the fecundating winds, then cause

Quality the rain to descend from the sky, in addition to that providing you with water (in abundance),

though you are not the guardians of its stores. (QURAISH, 3,4).

And there is not a thing but with Us are its treasuries, and We do not send it down except in a known measure. (Al-Hijr,21)

The Air Quali-

ty Health

We send the winds fertilizing, and We send down out of heaven water, from which you drink, and you are not its treasurers. (Al-Hijr, 22)

Drinking-

It is He who sends down water from heaven, which provides drink for you and brings forth

Water Quality trees on which your herds feed. (An-Nahl, 10)

Children of Adam, take your adornment at

Water Con-

sumption every place of prayer. Eat and drink, and do not waste. He does not love the wasteful. (Al' A'raf, 31)

And We send down purifying water from the

Water Bodies sky, that with it, we may give life to a dead land, and slake the thirst of things We have created, cattle and men in great numbers. (AlFurqan,48, 49)

Urban Structure Quality (USQ)

Quality of Air

Urban Design

Dimensions

(UDD)

Ethical Aspects (EA)

Green and responsible use air as a mode of transportation

Enhance and boom air car area

Annual average the volume of air pollutants

(e.g., TSP, Particulate Matter, Sulfur Oxide, Nitrogen Oxide)

Lessen $\mathrm{SO} 2 / \mathrm{CO} 2$ emissions in line with rectangular meter/esales

The Environmen- Reduce dirt which includes heavy metals like

tal Dimension

Reduce dirt which includes heavy metal
chromium, nickel, cobalt, and so on.

Switch stores/branches to natural CO2 refrig-

The Behaviora

Dimension

erant

Lessen avenue miles and boom miles in line with gallon

One hundred\% removal of ozone depletion

Citizens' belief in air pollution as a problem

Construct wind generators to provide inexperienced power

Atmospheric purification measures

Generating Energy,

Pollination, Fertilizing

Use energy produced by using wind energy and Causing Rains.

\section{Urban Structure Quality (USQ)}

The Environmen- Priorities the usage of freshwater

tal Dimension Improve Water-use efficiency

The Behavioral

Dimension

Safe and affordable drinking water

Access to A Continuous and High-Quality Supply of Water.

Reduce mains water use

Fit water-saving applications to colleagues,

customers, suppliers, etc.

Water quality and recycling

Appreciating Water's

The Environmenta

Dimension

The Behavioral

Dimension

Wers spoil,

or waste it.

Responsibility to not abuse or pollute it

Protect water-related ecosystems

Adequate sanitation and hygiene

Protect and Conserve Water for The Preservation of Different Forms Residents' Perception of Water Pollution as of Life On The Earth. a Problem
General Goal (GG)

from This Re-

or Polluting It.

Make Sure Right Comfort Conditions and Healthful Surroundings.

Control Emissions and Pollutants.

Preservation of Public Health.

Preservation of Public Health.
The Purification of The Atmosphere in

and General.

(a)

\section{Quality of Water}

Water Is A Condition for Survival, Existence, Growing, And Cleaning Dirty.

Safe Water for Human Recreational Use and Activities. 
Remediation of Do not make mischief in the earth after it has Contaminated been put right. Pray to Him with fear and Land hope; His Mercy is near to the righteous. (Al' A'raf, 56)

Allah created the heavens and the earth and sends down water from the heaven with Habitat Preser- which He brings forth fruits for your provivation. sion. He has subjected to you ships which, by His command, run upon the sea. He has subjected to your rivers, (Ibrahim, 32)

And of His signs is that He loses the winds as bearers of glad tidings, so that He lets you taste His Mercy and that the ships may sail at His command so that you can seek His bounty and be thankful. (Ar-Rum, 46)

Energy Con- It is He who shows you the lightning, for fear sumption and hope, and Who produces laden clouds. The thunder exalts His praise, and so are the angels are in awe of Him. He loses the thunderbolts and smites whosoever He will. Yet they dispute about Allah who is Mighty in power. (Ar-Ra'd, 12, 13)

\section{Urban Structure Quality (USQ)}

Responsible land use

Prevent, minimize, rehabilitate and offset the impact on land and its resources

Reduce eyesores such as soil erosion, wasterock piles, open pits, etc.

\section{The Environmental} Dimension

The Behavioral

Dimension crops, etc.

benefits of using minerals,

Integrate biodiversity management

Reduce/eliminate waste sent to landfill

Proper use of Fertilizers \& Pesticides

Set Action Plan for Biodiversity

Nature preservation

Efficient use of these free lands by cultivating

crops, trees, or constructing houses.

\section{Urban Structure Quality (USQ)}

Benefit from minerals,

plants, and animals

derive from land

soil to cultivate crops All the Human Activities.

and vegetables, etc.

\section{Quality of Land}

\section{Obligation to Protect All Kinds of Land; No} Exploitation or Carelessness, Etc.

Renewable Energy Projects

Use Solar Panels to Produce Electricity

Use Biofuels as A Natural Source of Energy

Invest in Solar Panels to Create Green Heat and

The Environmental Power

Dimension

Zero Harm, Zero Waste or Abuse

Extend Green IT and R\&D Eco-Programs to Care

The Behavioral

These Scarce Resources

Dimension
Decrease of the

primary

demand.

Alternative use of

resources supply.

\section{Rational Use of Resources}

enefit from the massive uses of these resources, mainly the non-living resources (e.g., Mountains, Stars, and Moon) Like all living things, these resources also deserve respect, protection, and care

Avoiding Extravagant Consumption of $\mathrm{Re}$

Electrical Efficiency Level

Reduction of Offensive Forces 
And thereby He brings forth crops and olives, palms and vines, and all the fruits. Indeed, in this, there is a sign for a nation who thinks. (An-Nahl,

He brings forth gardens, trellised and unrealized, palm trees and crops, different to eat, and the olive and pomegranates alike and unlike. When it olive and pomegranates alike and unlike. When it bears fruit, eat it and pay what is due to it upon not love the wasteful. (Al-'An'am, 141)

Outdoor

Acoustic com-

fort

And be moderate in thy pace and lower thy voice, for the harshest of sounds, without doubt, is the braying of the donkeys. (Luqman, 19

and We made your sleep a rest, and We made the night a mantle, and We made the day for a livelihood. (An-Naba', 9-10-11)

That which is on earth We have made but as a glittering show for the earth, so that We may test

Outdoor Visual Comfort them, as to which of them are best in conduct ( $A$ -Kahf, 7)

Do you not see how your Lord stretches the shadow? Had it been His will, He could have made it constant. Then He appointed the sun to be a guide to it; (Al-Furqan, $\mathbf{4 5}$ (
Urban Structure Quality (USQ)

Quality of Local Environment

Green Vicinity Percentage

Being capable of

revel in herba

andscapes and

Increase outdoo thermal comfort.

\section{Ease of Arrival to Green Area}

Provide Comfortable Conditions Within

Urban Areas.

Guarantee the ongoing lifestyles of discomfort during plants and animals and maintenance of summer biodiversity.

months in public Respecting divinity and others' privacy spaces and walk-

The Functional

Dimension

Responsibility to Protect All Kinds of Plants, No Abuse, Or Exploitation, Or Carelessness, Etc.

Reduction of the

Impact of Odo

The number of times the noise limits for residential areas are exceeded annually

Apply measures to limit the noise transmission and use different criteria

Citizens' Belief in Noise Pollution as A Problem

to secure the proper sonic environment.

\section{The Environmental}

Dimension

Outside Surfaces Remedy for Glare Control

\section{The Behavioral Di-}

mension
Improve the Visible Com-

Designing for Sun and Shade 
Table 3 Qur'anic Physical Responsibility: ENS, EA, and GG, based on the 4 HNA, 9 HNI, and 5 UDD, source: (author)

Themes

Urban Struc-

ture Indicator

(USI)

It is Allah Who made your habitations homes of rest and quiet for you; and made for you, out of the skins of animals, (tents for) dwellings, which ye find so light (and handy) when ye travel and when ye stop (in your travels), (AL-Nahl,80)

We did not send Messengers before you but that they Use ate food and walked about in the markets; ... (AlFurqan, 20)

(or Read!) In the name of thy Lord and Cherisher, Who created, created man, out of a (mere) clot of congealed blood: Proclaim! and thy Lord is Most Bountiful, He Who taught (the use of) the Pen. (Al-'Alaq ,1,5) And when I am ill, it is He Who cures me; (AL-

Neighborhood Nor forget thy portion in this world: but do thou good, Services and as Allah has been good to thee, and seek not Facilities (occasions for) mischief in the land (Al-Qasas,77)

If it were not that mankind would be one nation, We would have made for whosoever disbelieves in the Housing \& Merciful silver roofs upon their houses, and stairs to Buildings climb, with doors to their houses and couches on climb, with doors to their houses and couches on
which to recline. Gold, surely, all this is but the enjoyment of this present life. The Everlasting Life with your Lord is for those who fear (Him). (Az-Zukhruf,33,34,35)
Urban Design Dimensions (UDD)

\section{Urban Structure Quality (USQ)}

Land Use

Ethical Aspects (EA)

Diversity Index

Community Completeness

Effective Use of Land (Or Land Reuse)

Gross Residential Density

Floor-Area Ratio

The Function

Dimension

Graded Density

Building Line

Properly Incorporated Automobile Parking

Building Height-To-Width Ratio

Availability of Infrastructure

The Functional

Dimension

Availability of Services and Facilities

Degree of Cleanliness of Services

Degree of Attractiveness of Facilities

Urban Structure Quality (USO)

Combine Multiple Use or

Motive Inside A Shared

Building or Compact Ven-

ture Region

Effective and Efficient Use citizens' needs of centers

of Land.

Promote Livability, Walk environment.

Ability, And Transportation

Efficiency.

Well-defined urban space

that promotes the sense of

enclosure.

Enhance daily physical activity associated with alternative modes of transportation and compact development.

Well-used and defined urban spaces.

Appropriate Community

Services and Facilities.

Durability

Adaptation

Condition

The Functional

Average overcrowding

Dimension

Connect to facilities and infrastructure

Compliance with building regulations

Technology in Building

Policies / Responsibilities for management

Increase overall efficiency.

Provide appropriate she ter for fulfilling people's basic needs.

Give a sense of facilities

Fulfill Households' Needs. Sustainability of the deve ownership 


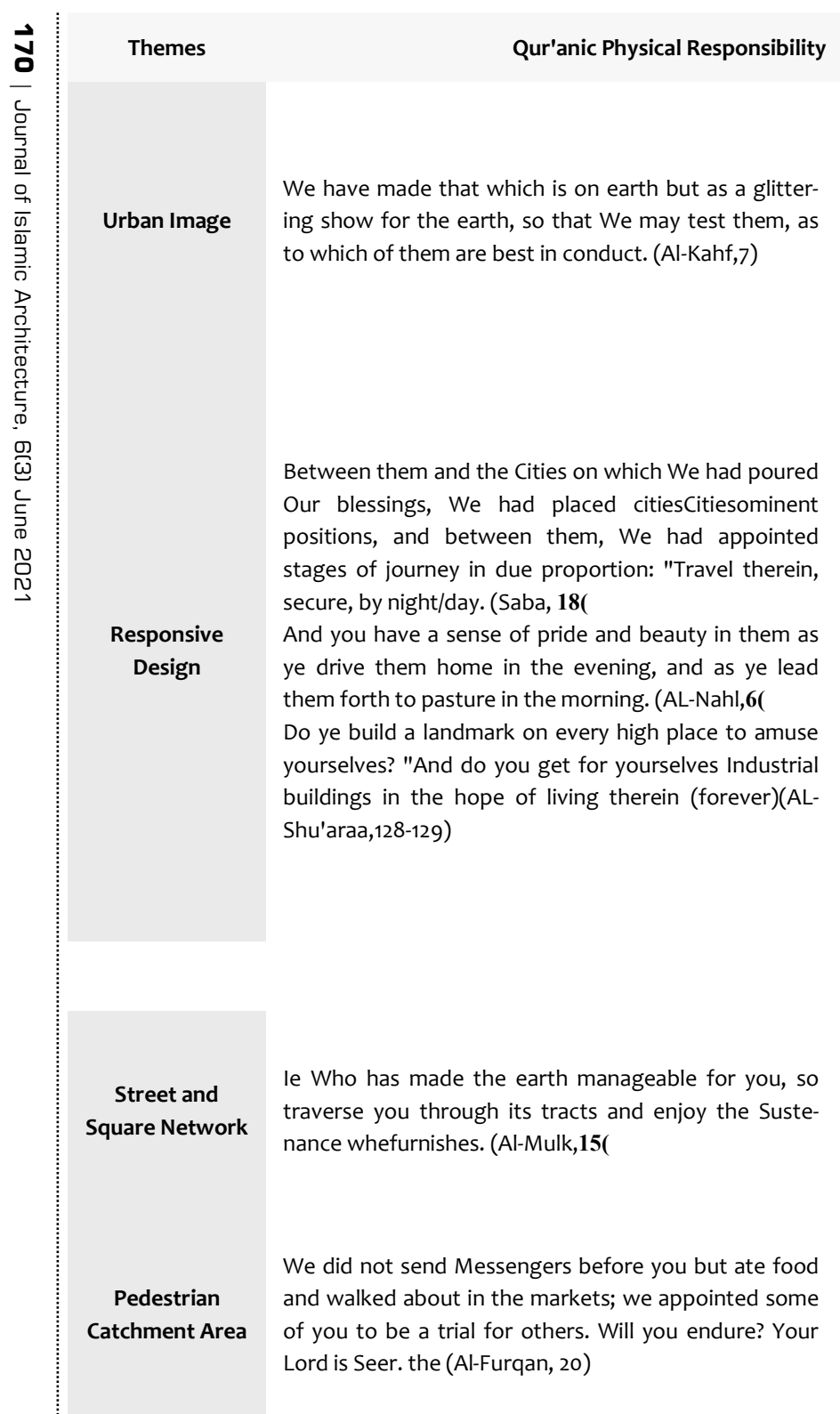

\section{Urban Structure Quality (USQ)}

Community Identity

Identified Paths

Identified Boundaries

Identified Focal Point

Define Neighborhood.

Identified Landmarks

The Functional Dimension

Local Vernacular

The Visual Dimen-

sion

Preserve Heritage Sites and Historical Remains

Support Positive Economic, Social and Environ-

The Perceptual mental Links Between Urban, Peri-Urban, and

Dimension

Rural Areas

The Temporal Dimension

Architectural \& Landscape Quality

Space Personalization / Personal Additions / Entry Personalization

Upgrade Slums

Building Sustainable and Resilient Buildings Utiliz-

ing Local Materials

Enhance inclusive and sustainable urbanization

Urban Structure Quality (USQ)

Mobility Urban

Complete Streets

Providing Proper Evacuation Routes

The Functional Dimension

Pedestrian Catchment Area for Facilities

Sidewalk quality / Sidewalk Network Coverage

Safe Pedestrian Crossing
A complete street network that promotes different uses and needs. reinforcing its own identity. Preservation heritage and historical Site Features.

strengthening national and regional development planning
Evoking Identity for Any Spaces.

Attractive Outdoor Scenery.

Realize the Visual- Aesthetic.

Creation of Environments That Users Can Modify and Adapt.

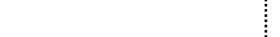


And be moderate in thy pace and lower thy voice, for the harshest of sounds, without doubt, is the braying of the donkeys. (Luqman, 19 (

Use Of Alternave Transporta-

tion

Have they not seen how We have created for them the cattle they master with Our Hands? We have subdued these to them, and some of them they ride and some of them they eat; (Yaseen, 71, 72)

Mischief has appeared on land and sea because of (the meed) that the hands of men have earned. That (Allah) may give them a taste of some of their deeds: Traffic Volume in order that they may turn back (from Evil). (AlRom,41)

Have they never journeyed through the land and seen what was the end of those who had gone before them? Allah destroyed them! Likewise, it is for the unbelievers (Muhammad, 10)
Use of Public Transport

Convenience / Safety of Public Transport

Affordability of Public Transport
The Functional Dimensio

\section{The Behaviora}

Dimension
Traffic Flow

Speed Limit
Minimize car dependency.

Provide a safe, comforta- Provide access to safe, ble, and affordable way of

transportation.

and sustainable transport area. ing road safety, notably by expanding public that links the dwellings to transport, with specia ttention to the needs of those in vulnerable situadren, persons with disabilities, and older per-

Reduce traffic congestion. Reduce traffic volume.

Reducing vehicle speeds Provide policy options to reduce traffic and its within the neighborhood. 
Table 4 Qur'anic Social Responsibility: ENS, EA, and GG, based on the 2 HNA, 6 HNI, and 3 UDD, source: (author)

Themes

Qur'anic Social Responsibility

Urban Struc-

ture Indicator

(USI)

$$
\text { Qur'anic Evidence (QE) }
$$

O mankind! We created you from a single (pair) of male and a female and made you into nations an tribes, that ye may know each other (not that ye may despise each other). Verily the most honored of you in the sight of Allah is (he who is) the most righteous

Social Justice

of you. ... (Al-Hujurat, 13

And caused them to depart from that in which they had been 'Co down.' We said, 'be enemies to each other. The earth will provide your dwelling enjoyment for a while (Al Baqarah,36)

And indeed, their Lord answers them: 'I do not waste the labor of any that labors among you, male or female you are from each other. (Aali' Imran, 195)

O Prophet, when believing women come to you an swear loyalty to you upon the condition that they wil not associate anything with Allah, and will not stea,

Gender Equal- nor commit adultery, nor slay their children, nor fabricate slander between their hands and their feet, nor disobey you in any honorable thing, supplicate to Allah for forgiveness for them, Allah is the Forgiving and the Most Merciful. (Al-Mumtahana, 12)

There I found a woman ruling over them. She posThere 1 found a wom
Urban Structure Quality (USQ)

Social Equity and Inclusion

Urban Design Di-

mensions (UDD)

Ethical Aspects (EA)

General Goal (GG)

Equal Access to Affordable Housing

Equal Access to Services and Facilities

Behavioral Performance

Inclusive Communities

Eliminate gender violence

De Behavioral

Dimension

The Socio-Cultural Dimension

End harmful practices against children and wom-

Provision of public services (Cultural Facilities Social Facilities - Religious Facilities - Telecom.

Services - ...etc.

Behavioral control. Sense of stability. vital public realm.

Leadership position for women

able the widest spectrum of people, regardless of age or ability, to more easily participate in community life by increasing the proportion of areas usable by people.

Prevent social inequalities and foster a socially inclusive community.

Achieving equality and justice

Equal opportunities for men and women in economic life, eliminat orms of vilence form of violence against win ing early and forced marriage, and equal participa 
Proclaim! (Or Read!) In the name of thy Lord and Cherisher, who created, created man, out of a (mere) clot of congealed blood: Proclaim! And thy Lord is Most Bountiful, He Who taught (the use of) the Pen, Quality Educa- Taught man that he knew not. (Al-'Alaq ,1,5) Say: 'Are they equal, those who know and those who do not know? 'Only those with minds remember. (Az-Zumar,9)

But it is only those amongst His worshippers that fear Allah who has knowledge... (Fatir,28)

Believers do not consume your wealth among yourceod Health in falsehood, except trading by your mutua and Wellagreement. And do not kill yourselves. Allah is the agreement. And do not kill yourselve
Most Merciful to you. (An Nisa',29)

Being

Spend in the way of Allah and do not cast into de struction with your own hands. (Al Baqarah,195)

This present life is like the water. We send down from the sky. The plants of the earth mix with it and from it mankind and cattle eat; then when the earth has

Social Partici- become lush and adorned, its inhabitants think the night or day, and We cause it to be stubble, just as though it had not flourished the day before. In this way, We distinguish Our verses for those who reflect. (Yunus, 24)

So, when you have finished (your prayer), labor (in supplication). (Al-'Inshirah, 7)

It is He Who made the sun to be a shining glory and the moon to be a light (of beauty), and measured out Time Manage- stages for it; that ye might know the number of years ment and the count (of time). Nowise did Allah create this but in truth and righteousness. (Thus) doth $\mathrm{He}$ explains His Signs in detail, for those who understand. (Yunus,5(

By the night, when it envelops, and by the day when it unveils. (Al-Layl, 1,2)
Free primary and secondary education

Quality early childhood development

Equal access to career development

Build skills and capacities

Gender equality in education

Upgrade educational facilities

The Behavioral

Dimension

Healthy life expectancy

Reduce child mortality

The Socio-Cultural

Dimension

End epidemics

Half traffic-related death

legislations for Supporting and Organizing

Community Participation

Participation in Planning Processes

Participation in maintenance and management

Public Awareness

Realizing the importance of time

The Behavioral

Dimension

The Temporal Di-

mension

Time Management \& Management of sudden

The importance of education and good-quality training in improving the living conditions of individuals, communities, and entire societies.

emphasizes equity and quality of education in a life-long learning approach,

\section{tions.}

Support a variety of human activities.

Ensure universal access to

All people should have access to good-quality healthcare and medicines, including financial risk proection.

sexual and reproductive

healthcare, including family

planning, information, and

education.

Promote a strong community about how it should be improved or how it should Encourage responsiveness to change over time. community needs by involving the people who live or work in the community in project design and planning, and decisions.

Doing business and achieving goals

Take advantage of the efforts made to the fullest Knowing and setting priorities

The balance between work events 
Table 5 Qur'anic Economical Responsibility: ENS, EA, and GG, based on the 2 HNA, 4 HNI, and 1 UDD, source: (author)

Themes

Urban Struc-

ture Indicator

Good Jobs

Your Lord gives to whom He will His provisions both abundantly and sparingly. He is aware and sees His worshipers. (Al-'Isra', 30)

Believers do not consume your wealth among yourEconomic selves in falsehood, except there be trading by your Growth mutual agreement. And do not kill yourselves. ... (An Nisa', 29)

And do not keep your hand chained to your neck

Cost of Living (when spending), nor open it completely so that you will sit blamed and destitute. (Al-'Isra', 29)

... but it is righteousness to believe in Allah and the Last Day, and the Angels, and the Book, and the Messengers; to spend of your money, out of love for

No Poverty Him, for your kin for orphans, for the needy, for the wayfarer, for those who ask, and for the ransom of slaves; to be steadfast in prayer, and practice regular charity, to fulfill the contracts which you have made; (Al-BAORA, 177)
Urban Structure Quality (USO)

Economic Development

$\begin{array}{llll}\text { Urban Design Di- } & \text { Ethical Aspects (EA) } & \text { Basic Needs (BN) } & \text { General Goal (GG) }\end{array}$

Youth employment

Labor and Skills

Eradicate forced labor

Employment opportunities.

Protect labor rights

Productive employment and equal pay

The Socio-Cultura

Locally Owned Businesses

Business Priority Sectors

reate additional permanent jobs within the local

area.

Support small enterprises

Upgrade industries and resource-use efficiency

Promote a local business.

Sustainable business practices

Public procurement practices

Urban Structure Quality (USQ)

Economic Standard of Living
The Socio-Cultural Dimension

Sustain income growth

Equal opportunities for all

Poverty rate

Poverty gap

The Socio-Cultur

Dimension
Cost of Services and Facilities

Resilience to disasters
Individual's ability to pur chase adequate housing and accommodations.

To ensure that people who have escaped poverty do not fall back into it, it envisBesides aiming to eradicate ages measures to strengthextreme poverty, it takes a en livelihood resilience, comprehensive approach to including establishing poverty by including a target social security systems. on relative poverty based on national definitions. 
Themes

Urban Struc-

ture Indicator

Urban Govern-

ance and

Management

Peace and

Justice is Hell, to abide therein (forever): and the wrath and the curse of Allah are upon him, and a dreadful penalty is prepared for him. (An-Nisaa, 93(

It is part of the Mercy of Allah that thou dost deal Community gently with them. Wert thou severe or harsh-hearted, Involvement they would have broken away from about thee: so, in Council pass over (their faults), and ask for (Allah's) forDecision giveness for them; and consult them in affairs (of the Making moment). Then, when thou hast taken a decision, put thy trust in Allah. .. (Al-i-'Imran,159

Allah doth command you to render back your Trusts to those to whom they are due; and when ye judge between man and man, that ye judge with justice: verily how excellent is the teaching which He gives you! For Allah is He Who hearth and seethe all things. (AL-Nisaa (58)

Urban Structure Quality (USQ)

Urban Policies and Strategies

The Behavioral

Dimension

Ethical Aspects (EA)

Basic Needs (BN)

General Goal (GG)

mensions (UDD)

Good Governance and Good Urban Management

Integrated Urban Governance

Efficient Law Enforcement

Codes and Guidelines

Reduce violent deaths

Reduce corruption

Develop effective institutions

Ensure inclusive and participatory decision making

Urban Structure Quality (USQ)

Develop clear national policies.

Improve ethics of city in the neighborhood with urban design codes and legislations.

Reducing all forms of vio lence, ending torture, and combating all forms of organized crime.

Reducing corruption and bribery as well as illicit financial and arms flows. Civil and Political Rights

The Behavioral

Dimension

The Socio-Cultural Dimension
Understanding How Councils Make Decisions

Confidence That Council Decisions Are in The Best Interests of The City

Public Influence on Council Decision Making

Partnerships for The Goals
Participation of residents in representative governance and decision-making processes at local and national Community involvement in decision-making. levels.
New development that supports ethics of city

Provide the framework and general conditions for the realization of the ethics of the city.

Promote peaceful and inclusive societies.

Promote inclusive institutions and the rule of law and guarantee equal access to justice. 


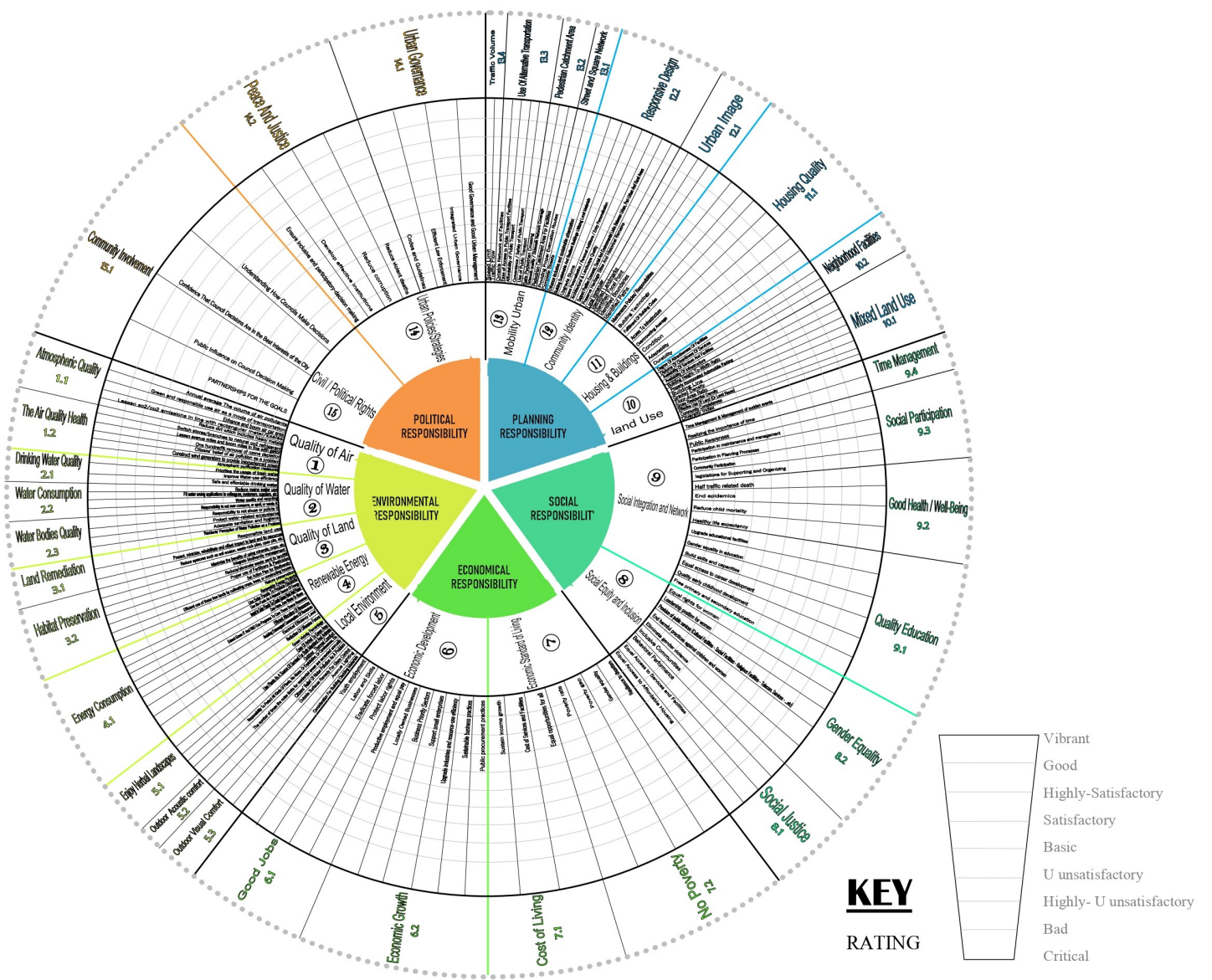

Figure 1 Circle of Qur'anic Ethics Responsibility towards Urbanism, source: (author)

\section{CONCLUSION}

In Islam, the Quran views the role and the duty of the human being as a moral, social responsibility of humanity and community, thus forming a standpoint for views involving respect for the surrounding environment Whether the environment is built or natural, improving the built environment: housing, water, sanitation, and related essential services, promotion and protection of human rights and access to justice, revitalizing the local economy and ensuring sustainable prosperity, and strengthen political and civil rights and widen participation in the decision-making process. Qur'anic urban responsibility ethics was focused on the interaction between humans and the environment (i.e., living and non-living things). In this context, Human responsibility towards God is argued to involve human responsibility towards urbanism and communities. Therefore, any means available should be employed to urge all persons commit themselves to Qur'anic ethics, morals, and manners of dealing with the urban structure, or their religious instructions or cultural guidance. There are two limitations to this study, however. The first is a result of the textual analysis of the Qur'an, i.e., the Qur'an and Sunnah are sig- nificant but not sufficient to cover the principal sources of Islamic law. Secondly, this study focuses on a single religion. It was outside the reach of this paper to explore parallels and disparities in the philosophy of ethical urbanism among various faiths. Despite that, these constraints open several spaces for future research. Both quantitative and qualitative analyses of the influential position of religions and the effect of religious beliefs on human behavior towards urban and its structure should be conducted.

\section{REFERENCES}

[1] A. Hope and C. Jones, "The impact of religious faith on attitudes to environmental issues and Carbon Capture and Storage (CCS) technologies: A mixed-methods study," Technology in Society, vol. 38, pp. 48-59, August 2014.

[2] Y. Al-Qaradawi, Safeguarding the environment in Islamic Sha-ria, Sharjah: Dar Al Khaleej, 2000.

[3] R. Kamla, S. Gallhofer and J. Haslam, "slam, nature and accounting: Islamic principles and the notion

176 | Journal of Islamic Architecture, 6(3) June 2021 
of accounting for the environment," Accounting Forum, vol. 30, no. 3, p. 245-265, 2006.

[4] G. Rice, "Islamic ethics and the implications for business," Jour-nal of Business Ethics, vol. 18, no. 4, p. 345-358, 1999.

[5] R. Rizk, "Islamic environmental ethics," Journal of Islamic Accounting and Business Researc, vol. 5, no. 2, p. 194-204, 2014.

[6] W. Murad, Philosophical Dictionary, Cairo: Dar Quba, 1998.

[7] O. Leaman, The Qur'an: An Encyclopedia, England: Routledge, 2006, p. 415.

[8] M. Al-Shahrastani, al-Milal wa al-Nihal (The Book of Sects and (reeds), Beirut : Dar Al-kotob AlIlmiyah, 2009, p. 17.

[9] H. Hassan, "From Moderate Idealism to Radical Realism," The memorial book on Tawfiq Al-Tawil, p. 83, 1995.

[10] H. Jeon, "The Interaction between the Just City and its Citizens in Plato's Republic: From the Producers' Point of View," Journal of the History of Philosophy, p. 183-203, 2014.

[11] M. Al-Sabouny, Safawt altafaseer: Tafseer Qur'an karim, Cairo: Dar Al-Sabouny for printing and publication., 1978.
[12] M. al-Sha'rawi, Interpretation of Al-Shaarawy or AlShaarawi's thoughts, Cairo: Today's News House Culture Sector, 1992.

[13] A. al-Sa'di, Tafseer al-Sa'di - Qur'an Exegesis, Damascus: Resalah Publisher, 2015.

[14] M. Al-Tabari, The Commentary on the Qur'an (Jami` al-bayan `an ta'wil 'ay al-Qur'an, commonly called Tafsir al-Tabari), A. M. Shaker, Ed., Al-Risala Foundation, 2000.

[15] A. Elshater, "Urban design redux: Redefining a professional practice of specialization," Ain Shams Engineering Journal, vol. 6(1), p. 25-39, 2015.

[16] A. Elshater, "Prosperity of thought versus retreat of application: A comprehensive approach in urban," International Journal of Architectural Research: ArchNet-IJAR, vol. 8(3), p. 45-63, 2014.

[17] A. Bagader, A. El-Sabbagh, M. Al-Gayand, M. Sa marrai and O. Llewellyn, "Environmental Protection in Islam," IUCN Environmental Policy and Law, p. 20, 1994.

[18] M. Al-Qurtubi, Tafsir al-Qurtubi is also known as AlJami'li-Ahkam or Al-Jami' li Ahkam al-Qur'an or Tafsir al-Jami', Cairo: The Egyptian Book House, 1964.

[19] I. Ibn Kathir, The great interpretation of the Qur'an (Tefsir ibn Kathir), M. H. S. al-Din, Ed., Beirut: Dar al-Kutub Al-Alami, Muhammed Ali Beydoun Publications, 1998. 